\title{
A consideration of polychlorinated biphenyls as a chemostratigraphic marker of the Anthropocene
}

\begin{tabular}{|c|l|}
\hline Journal: & The Anthropocene Review \\
\hline Manuscript ID & ANR-19-0030.R1 \\
\hline Keywords: & $\begin{array}{l}\text { Anthropocene, chemostratigraphic marker, environmental archives, } \\
\text { persistence, polychlorinated biphenyls }\end{array}$ \\
\hline Abstract: & $\begin{array}{l}\text { Polychlorinated biphenyls (PCBs), organic pollutants of anthropogenic } \\
\text { origin, were widely used in many industrial applications worldwide } \\
\text { roughly from the 1930s to the 1970s. Both the use and disposal of PCBs } \\
\text { contributed to their ubiquity in different environmental compartments } \\
\text { and they show extremely high persistence because of their high physical } \\
\text { and chemical stability. Concentrations of PCBs in environmental archives } \\
\text { located in different parts of the world usually show an initial increase in } \\
\text { the 1950s, and maxima in the 1960s-1970s followed by a sharp } \\
\text { decline following the ban in their use. Thus, the increase in PCB } \\
\text { concentrations would appear to be suitable as a chronostratigraphic } \\
\text { marker in Anthropocene strata. This manuscript discusses the PCBs } \\
\text { record in different environmental archives in the context of temporal and } \\
\text { spatial trends in production and application of these compounds as well } \\
\text { as the advantages and disadvantages of the use of PCBs in the } \\
\text { chemostratigraphy of the Anthropocene series. }\end{array}$ \\
\hline
\end{tabular}

\section{SCHOLARONE Manuscripts}




\title{
A consideration of polychlorinated biphenyls as a chemostratigraphic marker of the Anthropocene
}

\begin{abstract}
Polychlorinated biphenyls (PCBs), organic pollutants of purely anthropogenic origin, were widely used in many industrial applications worldwide roughly from the 1930 s to the 1970 s. Both the use and disposal of PCBs contributed to their ubiquity in different environmental compartments and they show extremely high persistence in the environment because of their high physical and chemical stability. Concentrations of PCBs in environmental archives located in different parts of the world usually show an initial increase in the 1940s-1950s, and maxima in the 1960s-1970s followed by a sharp decline following the ban in their use. Thus, the increase in PCB concentrations would appear to be suitable as a chronostratigraphic marker in Anthropocene strata. This manuscript discusses the PCBs record in different environmental archives in the context of temporal and spatial trends in production and application of these compounds as well as the advantages and disadvantages of the use of PCBs in the chemostratigraphy of the Anthropocene series.
\end{abstract}

\section{Keywords}

Anthropocene, chemostratigraphic marker, environmental archives, persistence, polychlorinated biphenyls 


\section{Introduction}

The beginning of the Anthropocene Epoch, which is being formally considered by the Anthropocene Working Group, is proposed to be the mid-twentieth century (Zalasiewicz et al., 2015; 2017). Thus, this geologic time unit differs from its precursors in Earth's history not only by its short duration, but also because it reflects human impact on a geological scale (Waters et al., 2016). This impact includes changes in both biotic and abiotic systems. Examples of markers of this impact that may support the eventual formalization of the Anthropocene as a geological time unit include changes in habitats and young fossil records (Kidwell, 2015; Williams et al., 2015), artificial radionuclides from nuclear bomb testing (Waters et al., 2015), technofossils and novel materials (Zalasiewicz et al., 2014; Gałuszka and Migaszewski, 2017), plastics (Zalasiewicz et al., 2016) and fly ash particles (Rose, 2015). Anthropogenic imprint on the environment is also clearly evidenced by pollutants accumulated over time in different environmental archives (Chiaia-Hernández et al., 2017; Gałuszka et al., 2017) and chemostratigraphic markers of the Anthropocene can be used to define the lower boundary of this chronostratigraphic unit and to indicate the Global Stratotype Section and Point (GSSP) required to define any new geological time period (Waters et al., 2018). Ideally, such markers should leave a global, synchronous, sharp and persistent signal at the start of the Anthropocene strata. One of the proposed chemical markers for the Anthropocene Epoch are persistent organic pollutants (Dachs and Méjanelle, 2010), including polychlorinated biphenyls (PCBs) (Gałuszka and Rose, 2019)-, PCBs are an important group of compounds included in the Stockholm Convention on Persistent Organic Pollutants because of their high persistence, their 
long-range transport in the atmosphere and their bioaccumulation and toxicity in organisms (UNEP, 2001).

Recently, Waters et al. (2018) have discussed different environmental archives and their role in the potential recommendation of the GSSP for the Anthropocene. They suggest that due to the need for a highly resolved chronology, the choice of paleoarchive may be found in a wide range of different types of deposits including marine, estuarine and lacustrine sediments, glacial ice, or ombrotrophic peat bog (Fiałkiewicz-Kozieł et al., 2016) and coral reef sequences. Except for coral growth bands, the PCB record in all of these principal environments is well known from various locations worldwide (e.g. Vane et al., 2011; Bigus et al., 2014; Pavlova et al. 2014; Naffrechoux et al., 2015; Steinlin et al., 2015; Yang et al., 2016; Combi et al., 2017). This knowledge, as well as other features of PCBs, such as their purely-synthetic origin, availability of data on historic production and emission trends and well recognized environmental fate make PCBs potentially one of the best chemostratigraphic markers of the Anthropocene.

The first synthesis of PCBs was in 1876, but the commercial production of these compounds started 53 years later, when the catalytic reaction of biphenyl with chlorine was developed (Schwarzbauer and Jovančićević, 2018). A total global production of PCBs in the period spanning 1930 to 1993 was estimated at 1,325,810 tonnes, of which $81.3 \%$ was manufactured in USA, West Germany, USSR (Russia) and France (Breivik et al., 2007).

Physical characteristics of PCBs, especially their excellent dielectric properties, resistivity to aggressive fluids such as acids or alkalis and extremely low flammability caused their wide 
application in many industrial sectors. The most common use of PCBs was in capacitors and transformers as filling fluids, but they were also used as lubricants, hydraulic fluids in mining, and as additives to paints, plastics, rubber, copying paper, solvent extenders and sealants. PCBs were used in both open and closed applications. The open-system applications (e.g. in paints and plastics) were forbidden in many countries in the 1970s (Schwarzbauer and Jovančićević, 2018). Closed applications include completely closed systems (e.g. electrical equipment) and nominally closed systems (e.g. vacuum pumps, heat transfer equipment). The most common of these (two-thirds of PCBs produced) were the former, of which about $70 \%$ are probably still in service (Broeg and Theobald, 2017). The primary sources of PCBs in the environment are related to these intentional uses, but also to their inadvertent generation during synthesis of different compounds, the disposal and improper management of PCBcontaining waste, and accidental releases (Breivik et al., 2002). Secondary sources include the release of PCBs from storage in melting glaciers (Bogdal et al., 2009), or re-emission of these pollutants from contaminated soils or sediments. As PCBs are semi-volatile compounds they easily undergo long-range transport in the atmosphere and this is important for their global distribution.

Here, we discuss the suitability of PCB records in environmental archives as a chemostratigraphic marker for the Anthropocene. Our focus is on the record of PCBs in different environmental archives but we also consider the possibility of signal the potential disadvantages of PCBs as a chronostratigraphic marker due to the lack of valid data on diagenetic changes of PCBs buried in sediments. Potential difficulties in selection of 
appropriate PCB congeners that meet the criteria of an ideal Anthropocene marker (global distribution and maximum persistence in environmental archives) are also outlined. The significance of this review is in the potential application of PCBs in the on-going debate aimed at the selection and recommendation of a GSSP for the proposed Anthropocene Epoch (Waters et al., 2019).

\section{Characteristics and environmental fate of PCBs}

PCBs are synthetic chemicals having a general chemical formula $\mathrm{C}_{12} \mathrm{H}_{10-n} \mathrm{Cl}_{n}$ and encompassing 209 congeners that depend on the number and position of chlorine atoms in their molecule

(Fig. 1). Each congener may contain up to ten chlorine atoms in the molecule. A characteristic feature of PCBs is that these compounds always occur in mixtures, both in technical products and in the environment, but usually, for practical reasons, only selected congeners are determined in environmental samples (Risso et al., 2016). The Stockholm Convention on Persistent Organic Pollutants, recommend that the six most abundant congeners (numbers 28, $52,101,138,153$ and 180) should be measured (IARC, 2016) while the International Council for the Exploration of the Sea, recommend reporting these six congeners plus the mono-ortho congener PCB-118.

In commercial mixtures PCBs occur as viscous yellow or dark liquids, however, as single congeners at room temperature they are light yellow or colorless crystals. PCBs are lipophilic (log $\mathrm{K}_{\text {ow }} 3.9-8.2$ ) and have a low vapor pressure (from $6.3 \times 10^{-6} \mathrm{~Pa}$ at $25^{\circ} \mathrm{C}$ for nonachlorobiphenyl to $1.1 \mathrm{~Pa}$ at $25^{\circ} \mathrm{C}$ for monochlorobiphenyl) (IARC, 2016). Commercial PCB 
products differ in their congener composition depending on the manufacturer. They usually consisted of $100-140$ congeners with a total chlorine content in the range of $21-68 \%$ (IARC, 2016).

Because PCB congeners differ in their physicochemical properties, including molecular weight, solubility in water and volatility, their fate in the environment differs. In general, congeners with a higher number of $\mathrm{Cl}$ atoms in their structure have lower water solubility and vapor pressure than lower-chlorinated congeners, but their persistence and lipophilicity are higher (Shiu and Mackay, 1986). Consequences of these differences for transport, accumulation and persistence in various environments will be discussed in the next two sections.

\section{PCBs in environmental compartments}

PCBs are ubiquitous in environmental compartments. They are poorly soluble in water and tend to accumulate in sediments, soils and living organisms. As a consequence, their lowest concentrations are found in air $\left(10-1000 \mathrm{pg} / \mathrm{m}^{3}\right)$ and water $(\mathrm{ng} / \mathrm{L})$, whereas the highest concentrations are recorded in sediments and animal tissues (up to several thousand $\mathrm{ng} / \mathrm{g}$ ). Despite low levels of PCBs in the air as a consequence of relatively low vapor pressures, longrange atmospheric transport is the most important pathway for global dispersal. Currently, the major sources of PCBs in the atmosphere are: incineration processes, contaminated biomass burning, volatilization from contaminated water and soil, waste electrical and electronic equipment, as well as inadvertent formation during pigment production (Eckhardt et al., 2007; Khairy et al., 2015; Vorkamp, 2016; Breivik et al., 2016). 
PCBs may occur in the air partly as vapors and partly as a fraction adsorbed onto particulates and the partitioning of PCBs between gaseous and particulate phases depends on temperature. Higher temperatures favor volatilization of PCBs, whereas at lower temperatures they tend to condense and be deposited (Wania and Mackay, 1993) and this process governs spatial and seasonal changes in PCB concentrations in the air. Moreover, a reversible deposition-volatilization exchange between the air and terrestrial/aquatic environments is observed (Eckhardt et al., 2007). Molecules with a higher number of $\mathrm{Cl}$ atoms occur mostly in the particulate-phase and are more easily deposited than lower-chlorinated compounds. This exchange allows the movement of PCBs, especially the more volatile congeners, to move from tropical and temperate regions to higher latitudes in a series of volatilization-transportdeposition 'hops' known as the 'grasshopper effect'. In this manner, more volatile PCBs may move preferentially to higher latitudes while less volatile congeners remain in warmer regions. This process has been termed 'global distillation' and may also occur as a result of lower temperatures due to increased altitude, rather than latitude. Hence, gradients in less volatile PCB concentrations maybe observed with altitude in the lakes, soils and organisms of mountain regions (Grimalt et al., 2004).

Although some studies have suggested that PCBs could be produced from natural sources (e.g. Berset et al. 2001; Zennegg et al 2007) any natural production may be considered negligible in comparison with anthropogenic sources. Global atmospheric emissions of PCBs reached their peak values of 3,000 tonnes/year in the 1970s and had declined to several hundred tonnes/year by the 2010s (Breivik et al., 2002; 2007) as a result of restrictions in production 
following the ban in their use (Carlsson et al., 2018). In a study on air and fish of the North American Great Lakes, Hites and Holsen (2019) showed that the PCB degradation 'half-life' i.e. the time taken for concentrations to reduce by a factor of two, was 9-17 years, resulting in an exponential decline. By contrast, some PCB congener concentrations remain elevated. Concentrations of 3,3'-dichlorobiphenyl (PCB-11), which is inadvertently formed during production of yellow pigments, have not decreased since 2004 (Hites, 2018) while PCB emissions from e-waste management, recycling facilities, dumpsites and illegal burning are now important sources especially in Africa and Asia (Chakraborty et al., 2018; Hogarh et al., 2018; Liu et al., 2019).

PCBs may also be transformed in the atmosphere. For example, the reaction of PCBs in the gaseous phase with hydroxyl radicals leads to their degradation to chlorinated benzoic acids (Brubaker and Hites, 1998) and transformation by photodegradation results in the formation of hydroxylated and/or metoxylated PCBs (Sedlak and Andren, 1991; Tang et al., 2018). Deposition of PCBs from the atmosphere increases concentrations in surface waters and soils which, depending on environmental factors and volatility of specific congeners, may be a sink and/or a secondary source of PCBs. In water, PCBs that are either partitioned into dissolved or particulate-bound phases, can be transported with water flow, deposited with particulates or fecal pellets to bottom sediments, or taken up by aquatic organisms. Because of their very low water solubility, PCBs in aquatic environments occur mostly associated with suspended particles and sediments. They have been recorded in sediments of the remotest areas including the southern Mariana Trench at depths of 7000-11,000 m (Dasgupta et al., 2018). 
Interestingly, these deepest ocean samples revealed much higher PCB concentrations than sediment samples collected from shallower marine locations ( $<500 \mathrm{~m}$ to $2500 \mathrm{~m}$ ) (Dasgupta et al., 2018) and may be due to a lower rate of sedimentation in abyssal environments. A strong adsorption of PCBs to macro- and microplastics in the aquatic environment has been reported (Velzeboer et al., 2014) and these may also be a source to marine sediments.

PCBs accumulated in aquatic sediments may be transferred back to water through desorption, gas convection and bioturbation (Urbaniak, 2007). In sediments enriched in organic matter (OM), PCBs may be released from sediments to water following organic decomposition (deBruyn and Gobas, 2004). More direct inputs such as industrial effluents, landfills and urban run-off are also major sources of PCBs to surface waters.

Similarly to water, soils can be both a source of PCBs (re-mobilization of lower-chlorinated congeners) and a sink (higher-chlorinated congeners), but congener composition in soils may change through microbial activity. Aerobic microorganisms are responsible for dechlorination of lower-chlorinated PCBs, whereas anaerobic microorganisms participate in the degradation of highly-chlorinated to lower-chlorinated PCBs (Abramowicz, 1995). Forest soils are usually enriched in PCBs in comparison with soils in unforested areas as a result of scavenging of pollutants from the air by trees and transport with falling leaf litter to forest soils (forest filter effect) (Nizetto et al., 2006) or following rainfall, by washing accumulated PCBs from leaves to the forest floor (throughfall).

Plants take up PCBs from the air and transfer them into the food chain but root uptake and translocation from root to leaves is considered negligible (Tato et al., 2011). However, root 
exudates are important in plant-microbial interactions in the rhizosphere and thus facilitate PCB biodegradation (Terzaghi et al., 2018; Pino et al., 2019). Concentrations of PCBs dramatically increase through many food chains (Corsolini and Sarà, 2017). Such biomagnification is caused by the bioaccumulation of these compounds in the fat tissue of animals during the consumption of lower trophic levels. There is an extensive literature on PCB transfer through terrestrial and aquatic food-chains, including human exposure, but this is beyond the scope of this review (e.g. Ross et al., 2004; Blankenship et al., 2005; Burreau et al., 2006).

\section{Stability and transformations of PCBs in environmental archives}

Persistence of PCBs in environmental archives is a key issue when discussing their suitability as a chemostratigraphic marker for the Anthropocene. Despite their very high stability in different environmental compartments, PCBs undergo biodegradation in soils and sediments. Biodegradation depends on the degree of chlorination in the congener, physico-chemical and environmental factors (i.e. redox potential, temperature, $\mathrm{pH}$ ) and optimal conditions for bacterial growth (Borja et al., 2005). Reductive dechlorination of highly-chlorinated PCBs ( $\geq 5 \mathrm{Cl}$ atoms) occurs under anaerobic conditions, whereas aerobic bacteria transform lowerchlorinated PCBs (<4 Cl atoms) into chlorobenzoic acids (Abramowicz, 1995). PCBs with two Cl atoms in the ortho-position of a single ring (2,6- or $\left.2^{\prime}, 6^{\prime}-\right)$ and each ring $\left(2-2^{\prime}\right.$ or 6,6') (Fig. 1) are the most resistant to biodegradation (Borja et al., 2005).

Fractionation of PCBs is a natural process resulting in changes to the congener profile in the 
original commercial products following preferential partitioning of different congeners into environmental compartments and organisms, as well as volatilization and transformation. An example of such a fractionation process is the surface melting and refreezing of firn and ice which results in the accumulation of impurities on the surface of ice and decreased albedo (Pavlova et al., 2014). This also affects the partitioning of PCBs from the dissolved to the particulate phases as well as changes in congener profile as lower chlorinated PCBs are easily eluted with meltwater.

By contrast, studies on marine sediment cores collected from the Palos Verdes Shelf (California, USA), where municipal wastes had been deposited for about 45 years, showed no indication of PCB transformation by diagenetic processes (Eganhouse et al., 2000). Furthermore, in a study on weathering of marine sediments stored for 5 years in an outdoor environment after dredging, Couvidat et al. (2018) showed that concentrations of PCBs remained constant whereas the concentrations of other organic pollutants, such as polycyclic aromatic hydrocarbons and organotin compounds substantially decreased. Hence under favorable sedimentary conditions, environmental records of PCBs may remain stable for many decades and possibly centuries.

\section{Historical production and use of polychlorinated biphenyls (PCBs) worldwide}

Because PCBs were intentionally produced chemicals, reliable data on trends in their production are readily available (Table 1). Globally, the production of PCBs worldwide has been estimated at approximately 1.3 million tonnes (Zhao et al., 2017) and peaked in the 
1960s-1970s.

Different PCB congener mixtures were produced by various companies under different trade names. Production of tri-, tetra- and penta-chorinated biphenyls amounted to more than $72 \%$ of PCB homologues (Fig. 2) while total content of mono-CB, nona-CB and deca-CB in produced mixtures was lower than $1 \%$. Trade names of $\mathrm{PCB}$ products with details regarding their composition can be found elsewhere (e.g. IARC, 2016).

Global trends in consumption of PCBs show that-clear latitudinal trends with almost $97 \%$ of these compounds were-used in the Northern Hemisphere (Breivik et al., 2002). However, PCBcontaining products were used worldwide, including in South and Central America and Africa, where PCBs were not manufactured.

\section{Trends in PCBs pollution recorded in environmental archives}

Temporal PCB concentration trends recorded in different environmental archives depend on many factors, including proximity to the source, congener profile, climate, geographic location and specific features of the archive. The highest concentrations of PCBs are found close to facilities that manufactured PCBs where these compounds were accidentally or intentionally released to rivers and lakes (IARC, 2016). For example, in northwest South Carolina, USA, where the Sangamo-Weston capacitor manufacturing plant discharged effluents contaminated with PCBs into a stream feeding Lake Hartwell, sediment cores from the lake were found to contain up to $138,000 \mathrm{ng} / \mathrm{g} \Sigma_{107} \mathrm{PCBs}$ (Brenner et al., 2004). Similarly, extremely high concentrations of PCBs (up to $3 \cdot 10^{6} \mathrm{ng} / \mathrm{g}$ ) were found in fluvial sediments collected from near 
a former PCB production plant in Michalovce District, Slovakia (Kocan et al., 2001).

A range of environmental archives have been used to determine historical trends in PCBs in both remote and polluted areas. PCBs have been recorded in every location where they have been analyzed and may be considered to be globally ubiquitous.

\section{Remote regions}

Transport of PCBs in the atmosphere is considered the main transport pathway for PCBs to remote regions (Carlsson et al., 2018) and their semi-volatile nature and temperaturedependent transport in the atmosphere results in contamination of even the remotest sites located far from any direct source, such as the-Arctic high mountain regions and the deepest oceans (Table 2).

Many studies of PCBs have been conducted in polar and mountainous regions and there are several reasons for this. A condensation effect causes increased deposition of atmosphericallytransported PCBs at low temperatures while the grasshopper effect aids transport to higher latitudes and altitudes. PCBs are removed more slowly from remote regions than from historical source regions (Axelman and Broman, 2001) and therefore an increase in PCB concentrations in the Arctic is predicted from models (Carlsson et al., 2018). Lower-chlorinated congeners (tri- to penta-CBs) are more prone to long-range transport in the atmosphere. Thus, their concentrations in environmental samples collected in the Arctic are much higher than in samples collected in tropical areas, where these congeners are readily volatilized (Pavlova et al., 2014). In a recent study, which highlights a problem which may have been overlooked for decades, Bartlett et al. (2019) show how the synthesis of compounds during pigment 
production and hazardous waste incineration have resulted in PCB deposition to snow on Svalvard, although distinguishing between long-range and local transport to the site remained problematic. Furthermore, the release of PCBs and other persistent organic compounds from secondary sources in cold regions, mainly from meltwaters following glacial retreat is of concern and has been reported by many authors (Bogdal et al., 2009; Sharma et al., 2015; Pavlova et al., 2016). Remobilization of legacy PCBs from melting Himalayan glaciers and their transport to the Ganges River was reported by Sharma et al., 2015 while Schmid et al. (2011) studied PCB profiles in lacustrine sediment cores collected from two Alpine lakes situated at a distance of about $8 \mathrm{~km}$ from each other. One of the lakes (Lake Stein) was proglacial and the other (Lake Engstlen) was non-glacial. Peak concentrations in sediment layers dated to the period of PCB use in Switzerland was recorded in both lakes, but higher PCB content in younger sediments (dated to 1990s) was only observed in the glacial lake as a consequence of intensive glacier melting. There is no consensus about the future trends in PCB level changes in the context of climate changes, but an increase in air temperature will most likely lead to a global decrease in PCB concentrations in the environment. The degradation of persistent organic pollutants is known to increase by a factor of $2-3$ with a $10{ }^{\circ} \mathrm{C}$ temperature rise and so PCB degradation will be enhanced as global air temperatures increase (Nadal et al., 2015).

\section{Polluted sites}

Examples of $\mathrm{PCB}$ concentrations in environmental archives from polluted sites are shown in Table 3. Contamination from PCBs within heavily industrialized regions has been mostly caused 
by leakage from systems containing these compounds (Zhao et al., 2017). Extreme pollution of soils and fluvial sediments close to the condenser plant in the city of Serpukhov city-(Russia) with-show $\Sigma_{7} P C B$ tevels concentrations up to $1169 \mathrm{mg} / \mathrm{kg}$ in soil and $119 \mathrm{mg} / \mathrm{kg}$ in sediment were reported by (Malina and Mazlova, (2017).

Elimination of point sources of PCB pollution in developed countries has caused a clear decline in PCB concentration trends in environmental archives in the recent decades (Dachs and Méjanelle, 2010). The main sources of contemporary PCB pollution are the remaining PCBcontaining products that are still in use (Davies and Delistraty, 2016) but especially electric/electronic waste (e-waste) recycling facilities (Breivik et al., 2016). Chakraborty et al. (2018) found up to $488 \mathrm{ng} / \mathrm{g} \Sigma_{26} \mathrm{PCBs}$ in surface soils collected from informal e-waste recycling sites in India. However, e-waste is often transported from middle latitudes to subtropical and tropical regions, where PCBs are prone to volatilization and then, subsequently, to long-range atmospheric transport (Breivik et al., 2016) and-thereby likely to increase-increasing the

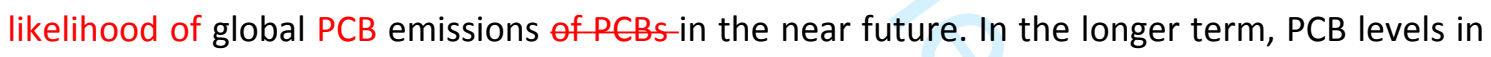
the atmosphere will continue to decline and become negligible. Although results of simulations and modelling studies show that if no additional regulatory measures are taken, PCB emissions will continue until at least 2100 (Li and Wania, 2016).

\section{Historical trends}

There are many examples of studies on the reconstruction of historic deposition of PCBs in environmental archives and especially in dated sediment cores. Some examples of the trends 
in different environmental archives are shown in Fig. 3. In the Northern Hemisphere, especially in Europe and North America, time trends in PCB concentrations in environmental archives usually show similar patterns with an onset during 1940s-1950s, a peak in 1960s-1980s and then a post-1980s decline. However, this trend of decreasing PCB concentrations has not been observed in remote areas of the Northern Hemisphere, and this may be explained by the lower volatilization of PCBs in cold regions (Axelman and Broman, 2001), secondary emissions of legacy PCBs from melting ice (Pouch et al., 2017), and an increase in global emissions of legacy PCBs caused by e-waste transport and recycling (Breivik et al., 2016).

The increase in PCBs in the 1930s and peak concentrations in the 1960s have been found in many locations. For example, in sediment cores from Lake Simcoe in south-eastern Canada (Helm et al., 2011) where PCB concentrations and trends correspond well with those recorded in sediment cores from the United States Great Lakes and with historical PCB emissions in the area.

Marine sediment cores show similar trends. Maximum PCB concentrations in sediment cores from the western Adriatic Sea between the 1960s and 1980s were recorded by Combi et al. (2016) and these decline significantly with concentrations reduced by up to $80 \%$ compared to peak values. Coastal Baltic Sea sediments also show the Northern Hemisphere pattern, with a trend of increasing PCB concentrations recorded by Sobek et al. (2015) in core sections dated to the 1940s-1960s and a peak in 1974. However, in offshore areas of the Baltic Sea, sediments showed elevated PCB concentrations in core sections from the 1960s-1980s with a peak in 1991 and which-this may be explained by lower sediment deposition rates in the offshore 
marine environment Only a slight decrease in PCB concentration is observed in both coastal and offshore sediments, suggesting that no significant reduction in PCBs may be expected in the near future (Sobek et al., 2015). Similarly, a 20 year lag in the appearance of PCBs in High Arctic lake sediments and their enrichment in more volatile congeners compared to lake sediments in lower latitudes as a result of global fractionation was observed by Muir et al. (1996).

Two periods of increase in PCB sediment profile from the continental shelf of the Korea Strait were found by Guerra et al. (2019). Peak values were recorded at the turn of the 1960s and also around 2000. The first increase in PCB concentrations correlates well with trends in PCB use from 1956 to 1983 . The later peak may be due to emissions from regional secondary sources.

In the Southern Hemisphere, sediment cores collected from Admiralty Bay in Antarctica showed a slight increase in PCB concentrations starting from 1970. Peak concentrations occurred in the late-1980s but there has been no significant decrease in the recent decades (Combi et al., 2017). In urbanized areas of the Southern Hemisphere, elevated levels of PCBs can also be found (Connel et al., 1999). For example, in sediments collected in the Santos estuary (Brazil) the maximum PCB concentration was $190.7 \mathrm{ng} / \mathrm{g}$ in the $1980 \mathrm{~s}$ (de Souza et al., 2018) declining in more recent decades and reflecting the slightly later peak in Brazilian emissions. However, while other sediment cores taken from this estuary showed similar trends, their peak PCB concentrations varied, occurring in the 1960s and c.1990. This suggests that dynamic environments such as the Santos Estuary may not be appropriate for defining an 
Anthropocene chemostratigraphy.

In summary, despite differences in absolute PCB concentrations in environmental archives from different locations, historical concentration patterns reflect trends in the use and/or production of these compounds (Lorgeoux et al., 2016). In general, in the Northern Hemisphere, the increase in PCB concentrations, observed in environmental archives from the 1940s-1950s may be considered as the most appropriate chronological marker while in the Southern Hemisphere, there is about a 20-year delay in the PCB record in environmental archives.

\section{Advantages and limitations of PCBs as a chemostratigraphic marker of the Anthropocene}

In comparison with other pollutants, PCBs have several features which make them a very good candidate for a chemostratigraphic marker of the Anthropocene. They are synthetic compounds and do not have negligible natural emission sources. This makes interpretation of temporal trends in their concentrations much easier than in the case of other organic pollutants, such as polycyclic aromatic hydrocarbons or inorganic pollutants, such as trace metals. Another advantage is their relatively long-term production (since 1929) and use which together with their semi-volatility and long-range atmospheric transport, which have led to the contamination of many environments around the world. Both environmental and health concerns have made this class of pollutants one of the most eften-studied in environmental samples worldwide. This has contributed to well-established analytical protocols for PCB determination in a wide variety of samples (Konieczka et al., 2010) and to a greater 
understanding of their global distribution of PCBs (Breivik et al., 2016). Availability of data on production, use and time trends in PCB concentrations recorded in environmental archives allow us to reconstruct the history of PCB pollution in many areas. Of great importance is also the high persistence of PCBs in the environment and their affinity with sediments which will provide a detectable signal over a long period of time.

The ability of microplastics to absorb and concentrate PCBs in sediments is also worth consideration in the context of chemostratigraphy (Velzeboer at al., 2014). This may be important for the Anthropocene as microplastics are another potential stratigraphic marker for this epoch (Zalasiewicz et al., 2016). PCB sorption onto microplastics in simulated seawater has been studied by Zhan et al. (2016). Chemical sorption was found to be the predominant mechanism while the sorption capacity of the plastic negatively correlates with particle size and temperature. Weathering and aging of microplastics increase their surface area and enhance their sorption capacities (Tourinho et al., 2019). Despite a lack of comprehensive knowledge on PCB sorption onto microplastics, it may be reasonable to use both microplastics and PCBs as combined markers for the Anthropocene.

However, while there are a number of characteristics that make PCBs good potential chemostratigraphic markers, there are some issues that may be problematic. These result mainly from physico-chemical features of specific congeners. Because of their higher volatility, lower-chlorinated PCBs predominate over higher-chlorinated $\mathrm{PCBs}$ in low temperature locations. Therefore, if a polar region were to be considered as a potential GSSP location, lower-chlorinated compounds would need to be determined in the archive. By contrast, in 
subtropical and tropical regions, environmental archives will be depleted in lower-chlorinated PCBs and higher chlorinated compounds would need to be considered.

Other potential disadvantages are their potential mobility, post-depositional processes and biodegradation. Lower-chlorinated PCBs show post-depositional mobility in sediments which may cause their appearance in sediment layers prior to the time of their production (Bigus et al., 2014). Furthermore, although degradation of PCBs is very slow, post-depositional processes may change their congener profiles. Biodegradation of PCBs occurs in both aerobic and anaerobic conditions. However, little is known about biodegradation in deeply buried sediments and knowledge of this process has only been determined from laboratory experiments (Borja et al., 2005 and references cited therein). As with many other stratigraphic markers, further problems occur as a result of the nature of the archives themselves. Apart from the loss of ice records due to glacial retreat and ice-cap loss, the PCB record in different environmental archives may be disturbed by a number of natural factors. For example, some authors claim that because lower chlorinated $\mathrm{PCB}$ congeners are more water-soluble than higher chlorinated congeners, they are mobile in ombrotrophic peats, which may causes postdepositional migration and hence introduces errors to the reconstruction of temporal trends in PCB emission and deposition rates (Sanders et al., 1995; Berset et al., 2001; Thüns et al., 2014). Furthermore, results from studies of tree rings as environmental archives of PCBs are scarce and inconclusive. Meredith and Hites (1987) did not find any relationships between concentrations in tree rings and $\mathrm{PCB}$ emission history in a $\mathrm{PCB}$ contaminated landfill in 
Bloomington, Indiana, whereas Odabasi et al. (2015) confirmed the usefulness of tree rings as environmental archives of $\mathrm{PCB}$ contamination.

Clearly, not all archives are appropriate for PCBs as chemostratigraphic markers although careful selection of archive, location and accumulating environment may overcome many of these disadvantages. Currently, it would appear that lacustrine and marine sediments offer the most promising sequences for a PCB chemostratigraphy.

\section{Conclusions}

Environmental records of PCBs may help find a suitable GSSP with which to formalize the Anthropocene as an epoch of geologic time. Of the different environmental archives that are under consideration for the Anthropocene GSSP, lake and marine sediments seem to be best due to their higher preservation potential for PCBs in comparison with ice, peat or corals. PCBs are ubiquitous and have been recorded in the remotest locations which means that they have met a key criterion of an ideal chemostratigraphic marker of the Anthropocene, which is a global range. If PCBs are to be considered as a chemostratigraphic marker, it is recommended that the initial increase in PCB concentrations in sediments dated from the mid-twentieth century be used as this is the most consistent on a global scale.

Another requirement for a chemostratigraphic marker is persistence. A lack of data on postdepositional changes in PCB concentrations in buried sediments does not allow us to give a straightforward answer to the question regarding the presence of PCBs in the strata of the far future. However, taking into account the results of laboratory experiments and the affinity 
of PCBs to organic substrates including microplastics, these compounds will most likely be preserved in sediments for, at least, many decades.

Chemostratigraphic markers, such as PCBs, are just one of the possible markers for Anthropocene strata and it is unlikely that only one marker will be used in the search for the Anthropocene GSSP. Thus, PCBs together with microplastics, artificial radionuclides, fly-ash and other anthropogenic signals may be utilized together for this purpose.

\section{Acknowledgements}

This paper is dedicated to the memory of Professor Jacek Namieśnik, the late rector of Gdańsk University of Technology, who died unexpectedly in April, 2019. He was a highly respected analytical and environmental chemist with whom A.G. and Z.M.M. have had the honor to collaborate for many years.

\section{References}

1. Abramowicz DA (1995) Aerobic and anaerobic PCB biodegradation in the environment. Environmental Health Perspectives 103(5): 97-99.

2. Axelman J, Broman D (2001) Budget calculations for polychlorinated biphenyls (PCBs) in the Northern Hemisphere-a single-box approach. Tellus B 53(3): 235-259.

3. Barakat AO, Mostafa A, Wade TL, Sweet ST, El Sayed NB (2012) Assessment of persistent organochlorine pollutants in sediments from Lake Manzala, Egypt. Marine Pollution Bulletin 64(8): 1713-1720. 
4. Bartlett PW, Isaksson E, Hermanson MH (2019) 'New'unintentionally produced PCBs in the Arctic. Emerging Contaminants 5: 9-14.

5. Berset JD, Kuehne P, Shotyk W (2001) Concentrations and distribution of some polychlorinated biphenyls (PCBs) and polycyclic aromatic hydrocarbons (PAHs) in an ombrotrophic peat bog profile of Switzerland. Science of the Total Environment 267(1-3): $67-85$.

6. Bigus $P$, Tobiszewski M, Namieśnik J (2014) Historical records of organic pollutants in sediment cores. Marine Pollution Bulletin 78(1): 26-42.

7. Blankenship AL, Zwiernik MJ, Coady KK et al. (2005) Differential accumulation of polychlorinated biphenyl congeners in the terrestrial food web of the Kalamazoo River superfund site, Michigan. Environmental Science \& Technology 39(16): 5954-5963.

8. Bogdal C, Schmid P, Zennegg M, Anselmetti FS, Scheringer M, Hungerbühler K (2009) Blast from the past: melting glaciers as a relevant source for persistent organic pollutants. Environmental Science \& Technology 43(21): 8173-8177.

9. Borja J, Taleon DM, Auresenia J, Gallardo S (2005) Polychlorinated biphenyls and their biodegradation. Process Biochemistry 40(6): 1999-2013.

10. Breivik K, Armitage JM, Wania, F, Sweetman AJ, Jones KC (2016) Tracking the global distribution of persistent organic pollutants accounting for e-waste exports to developing regions. Environmental Science \& Technology 50(2): 798-805. 
11. Breivik K, Sweetman A, Pacyna JM, Jones KC (2002) Towards a global historical emission inventory for selected PCB congeners-a mass balance approach: 2. Emissions. Science of the Total Environment 290(1): 199-224.

12. Breivik K, Sweetman A, Pacyna JM, Jones KC (2007) Towards a global historical emission inventory for selected PCB congeners-a mass balance approach: 3. An update. Science of the Total Environment 377(2): 296-307.

13. Brenner RC, Magar VS, Ickes JA, Foote EA, Abbott JE, Bingler LS, Crecelius EA (2004) Longterm recovery of PCB-contaminated surface sediments at the SangamoWeston/Twelvemile Creek/Lake Hartwell Superfund site. Environmental Science \& Technology 38(8): 2328-2337.

14. Broeg K, Theobald N (2018) Pollution with Hazardous Substances. In: Salomon M and Markus T (eds) Handbook on Marine Environment Protection. Cham: Springer, pp. 395412.

15. Brubaker WW, Hites RA (1998) Gas-phase oxidation products of biphenyl and polychlorinated biphenyls. Environmental Science \& Technology 32(24): 3913-3918.

16. Burreau S, Zebühr Y, Broman D, Ishaq R (2006) Biomagnification of PBDEs and PCBs in food webs from the Baltic Sea and the northern Atlantic Ocean. Science of the Total Environment 366(2-3): 659-672.

17. Cardellicchio N, Buccolieri A, Giandomenico S, Lopez L, Pizzulli F, Spada L (2007) Organic pollutants (PAHs, PCBs) in sediments from the Mar Piccolo in Taranto (Ionian Sea, Southern Italy). Marine Pollution Bulletin 55(10-12): 451-458. 
18. Carlsson P, Breivik K, Brorström-Lundén E et al. (2018) Polychlorinated biphenyls (PCBs) as sentinels for the elucidation of Arctic environmental change processes: a comprehensive review combined with ArcRisk project results. Environmental Science and Pollution Research 25(23): 22499-22528.

19. Chakraborty P, Selvaraj S, Nakamura M, Prithiviraj B, Cincinelli A, Bang JJ (2018) PCBs and PCDD/Fs in soil from informal e-waste recycling sites and open dumpsites in India: levels, congener profiles and health risk assessment. Science of the Total Environment 621: 930938.

20. Chiaia-Hernández AC, Günthardt BF, Frey MP, Hollender J (2017) Unravelling contaminants in the Anthropocene using statistical analysis of liquid chromatography-high-resolution mass spectrometry nontarget screening data recorded in lake sediments. Environmental Science \& Technology 51(21): 12547-12556.

21. Combi T, Martins CC, Taniguchi S, Leonel J, Lourenço RA, Montone RC (2017) Depositional history and inventories of polychlorinated biphenyls (PCBs) in sediment cores from an Antarctic Specially Managed Area (Admiralty Bay, King George Island). Marine Pollution Bulletin 118(1): 447-451.

22. Combi T, Miserocchi S, Langone L, Guerra R (2016) Polychlorinated biphenyls (PCBs) in sediments from the western Adriatic Sea: Sources, historical trends and inventories. Science of the Total Environment 562: 580-587. 
23. Connell DW, Miller GJ, Mortimer MR, Shaw GR, Anderson SM (1999) Persistent lipophilic contaminants and other chemical residues in the Southern Hemisphere. Critical Reviews in Environmental Science and Technology 29(1): 47-82.

24. Corsolini S, Sarà G (2017) The trophic transfer of persistent pollutants (HCB, DDTs, PCBs) within polar marine food webs. Chemosphere 177: 189-199.

25. Couvidat J, Chatain V, Bouzahzah H, Benzaazoua M (2018) Characterization of how contaminants arise in a dredged marine sediment and analysis of the effect of natural weathering. Science of the Total Environment 624: 323-332.

26. Dachs J, Méjanelle L (2010) Organic pollutants in coastal waters, sediments, and biota: a relevant driver for ecosystems during the Anthropocene? Estuaries and Coasts 33(1): 1-14.

27. Dasgupta S, Peng X, Chen S, Li J, Du M, Zhou Y-H, Zhong G, Xu H, Ta K (2018) Toxic anthropogenic pollutants reach the deepest ocean on Earth. Geochemical Perspectives Letters 7: 22-26.

28. Davies H, Delistraty D (2016) Evaluation of PCB sources and releases for identifying priorities to reduce PCBs in Washington state (USA). Environmental Science and Pollution Research 23(3): 2033-2041.

29. de Souza AC, Taniguchi S, Figueira RCL, Montone RC, Bícego MC, Martins CC (2018) Historical records and spatial distribution of high hazard PCBs levels in sediments around a large South American industrial coastal area (Santos Estuary, Brazil). Journal of Hazardous Materials 360: 428-435. 
30. de Voogt P, Brinkman UAT (1989) Production, properties and usage of polychlorinated biphenyls. In: Kimbrough KD and Jensen AA (eds) Halogenated Biphenyls, Terphenyls, Naphthalenes, Dibenzodioxins and Related Products. Amsterdam: Elsevier Science Publishers, pp. 3-45.

31. deBruyn AMH, Gobas FA (2004) Modelling the diagenetic fate of persistent organic pollutants in organically enriched sediments. Ecological Modelling 179(3): 405-416.

32. Dias-Ferreira C, Pato RL, Varejão JB, Tavares AO, Ferreira AJ (2016) Heavy metal and PCB spatial distribution pattern in sediments within an urban catchment-contribution of historical pollution sources. Journal of Soils and Sediments 16(11): 2594-2605.

33. Eckhardt S, Breivik K, Man $\varnothing$ S, Stohl A (2007) Record high peaks in PCB concentrations in the Arctic atmosphere due to long-range transport of biomass burning emissions. Atmospheric Chemistry and Physics 7(17): 4527-4536.

34. Eganhouse RP, Pontolillo J, Leiker TJ (2000) Diagenetic fate of organic contaminants on the Palos Verdes Shelf, California. Marine Chemistry 70(4): 289-315.

35. El Nemr A, El-Sikaily A, Khaled A, Said TO, Abd-Allah AMA (2004) Chlorinated pesticides and polychlorinated biphenyls in the coral reef skeleton of the Egyptian Red Sea coast. Bulletin of Environmental Contamination and Toxicology 72(6): 1195-1202.

36. Fiałkiewicz-Kozieł B, Smieja-Król B, Frontasyeva M et al. (2016) Anthropogenic-and natural sources of dust in peatland during the Anthropocene. Scientific Reports 6: 38731.

37. Fuoco R, Giannarelli S, Onor M, Ghimenti S, Abete C, Termine M, Francesconi S (2012) A snow/firn four-century record of polycyclic aromatic hydrocarbons (PAHs) and 
polychlorobiphenyls (PCBs) at Talos Dome (Antarctica). Microchemical Journal 105: 133141.

38. Gałuszka A, Migaszewski ZM (2017) Glass microspheres as a potential indicator of the Anthropocene: a first study in an urban environment. The Holocene 28(2): 323-329.

39. Gałuszka A, Migaszewski ZM, Namieśnik J (2017) The role of analytical chemistry in the study of the Anthropocene. TrAC Trends in Analytical Chemistry 97: 146-152.

40. Gałuszka A, Rose N (2019) Organic compounds. In: Zalasiewicz J, Waters C, Williams M, Summerhayes C (eds) The Anthropocene as a Geological Time Unit: A Guide to the Scientific Evidence and Current Debate. Cambridge: Cambridge University Press. pp. 186192.

41. Garmash O, Hermanson MH, Isaksson E, Schwikowski M, Divine D, Teixeira C, Muir DC (2013) Deposition history of polychlorinated biphenyls to the Lomonosovfonna glacier, Svalbard: a 209 congener analysis. Environmental Science \& Technology 47(21): 1206412072.

42. Grimalt JO, Fernandez P, Berdie L, Vilanova RM, Catalan J, Psenner R, Hofer R, Appleby PG, Rosseland BO, Lien L, Massabuau JC, Battarbee RW (2001) "elective trapping of organochlorine compounds in mountain lakes of temperate areas. Environmental Science \& Technology 35(13): 2690-2697.

43. Grimalt JO, Van Drooge BL, Ribes A, Vilanova RM, Fernandez P, Appleby P (2004) Persistent organochlorine compounds in soils and sediments of European high altitude mountain lakes. Chemosphere 54(10): 1549-1561. 
44. Guerra R, Pasteris A, Righi S, Ok G (2019) Historical record of polychlorinated biphenyls (PCBs) in the continental shelf of the Korea Strait. Chemosphere 237: 124438.

45. Guzzella L, Salerno F, Freppaz M, Roscioli C, Pisanello F, Poma G (2016) POP and PAH contamination in the southern slopes of Mt. Everest (Himalaya, Nepal): long-range atmospheric transport, glacier shrinkage, or local impact of tourism? Science of the Total Environment 544: 382-390.

46. He W, Bai ZL, Liu WX, Kong XZ, Yang B, Yang C, Jørgensen SE, Xu FL (2016) Occurrence, spatial distribution, sources, and risks of polychlorinated biphenyls and heavy metals in surface sediments from a large eutrophic Chinese lake (Lake Chaohu). Environmental Science and Pollution Research 23(11): 10335-10348.

47. Helm PA, Milne J, Hiriaert-Baer V, Crozier P, Kolic T, Lega R, Chen T, MacPherson K, Gewurtz S, Winter J, Myers A, Marvin CH, Reiner EJ (2011) Lake-wide distribution and depositional history of current- and past-use persistent organic pollutants in Lake Simcoe, Ontario, Canada. Journal of Great Lakes Research 37: 132-141.

48. Hites RA (2018) atmospheric concentrations of PCB-11 near the Great Lakes have not decreased since 2004. Environmental Science \& Technology Letters 5(3): 131-135.

49. Hites RA, Holsen TM (2019) Temporal trends of PCBs and DDTs in Great Lakes fish compared to those in air. Science of the Total Environment 646: 1413-1418.

50. Hogarh JN, Seike N, Kobara Y, Carboo D, Fobil JN, Masunaga S (2018) Source characterization and risk of exposure to atmospheric polychlorinated biphenyls (PCBs) in Ghana. Environmental Science and Pollution Research 25(17): 16316-16324. 
51. IARC (2016) Polychlorinated biphenyls. In: IARC Monographs on the Evaluation of Carcinogenic Risks to Humans, vol. 107. Polychlorinated and Polybrominated Biphenyls. Lyon: International Agency for Research on Cancer.

52. Khairy M, Muir D, Teixeira C, Lohmann R (2015) Spatial distribution, air-water fugacity ratios and source apportionment of polychlorinated biphenyls in the lower Great Lakes Basin. Environmental Science \& Technology 49(23): 13787-13797.

53. Khairy MA, Luek JL, Dickhut R, Lohmann R (2016) Levels, sources and chemical fate of persistent organic pollutants in the atmosphere and snow along the western Antarctic Peninsula. Environmental Pollution 216: 304-313.

54. Kidwell SM (2015) Biology in the Anthropocene: Challenges and insights from young fossil records. Proceedings of the National Academy of Sciences 112(16): 4922-4929.

55. Kocan A, Petrik J, Jursa S, Chovancova J, Drobna B (2001) Environmental contamination with polychlorinated biphenyls in the area of their former manufacture in Slovakia. Chemosphere 43(4-7): 595-600.

56. Konieczka P, Wolska L, Namieśnik J (2010) Quality problems in determination of organic compounds in environmental samples, such as PAHs and PCBs. TrAC Trends in Analytical Chemistry 29(7): 706-717.

57. Lécrivain N, Aurenche V, Cottin N, Frossard V, Clément B (2018) Multi-contamination (heavy metals, polychlorinated biphenyls and polycyclic aromatic hydrocarbons) of littoral sediments and the associated ecological risk assessment in a large lake in France (Lake Bourget). Science of the Total Environment 619: 854-865. 
58. Li H, Ye S, Ye J, Fan J, Gao M, Guo H (2017) Baseline survey of sediments and marine organisms in Liaohe Estuary: heavy metals, polychlorinated biphenyls and organochlorine pesticides. Marine Pollution Bulletin 114(1): 555-563.

59. Li L, Wania F (2016) Tracking chemicals in products around the world: introduction of a dynamic substance flow analysis model and application to PCBs. Environment International, 94, 674-686.

60. Liu R, Ma S, Li G, Yu Y, An T (2019) Comparing pollution patterns and human exposure to atmospheric PBDEs and PCBs emitted from different e-waste dismantling processes. Journal of Hazardous Materials 369: 142-149.

61. Lorgeoux C, Moilleron R, Gasperi J, Ayrault S, Bonté P, Lefèvre I, Tassin B (2016) Temporal trends of persistent organic pollutants in dated sediment cores: chemical fingerprinting of the anthropogenic impacts in the Seine River basin, Paris. Science of the Total Environment 541: 1355-1363.

62. Ma Y, Halsall CJ, Crosse JD, Graf C, Cai M, He J, Gao G, Jones K (2015) Persistent organic pollutants in ocean sediments from the North Pacific to the Arctic Ocean. Journal of Geophysical Research: Oceans 120(4): 2723-2735.

63. Malina N, Mazlova EA (2017) Temporal and spatial variation of polychlorinated biphenyls (PCBs) contamination in environmental compartments of highly polluted area in Central Russia. Chemosphere 185: 227-236.

64. Meredith ML, Hites RA (1987) Polychlorinated biphenyl accumulation in tree bark and wood growth rings. Environmental Science \& Technology 21(7): 709-712. 
65. Miao XS, Swenson C, Woodward LA, Li QX (2000) Distribution of polychlorinated biphenyls in marine species from French Frigate Shoals, North Pacific Ocean. Science of the Total Environment 257(1): 17-28.

66. Muir DC, Omelchenko A, Grift NP, Savoie DA, Lockhart WL, Wilkinson P, Brunskill GJ (1996) Spatial trends and historical deposition of polychlorinated biphenyls in Canadian midlatitude and Arctic lake sediments. Environmental Science \& Technology 30(12): 36093617.

67. Nadal $M$, Marquès $M$, Mari $M$, Domingo JL (2015) Climate change and environmental concentrations of POPs: A review. Environmental Research 143: 177-185.

68. Naffrechoux E, Cottin N, Pignol C, Arnaud F, Jenny JP, Perga ME (2015) Historical profiles of PCB in dated sediment cores suggest recent lake contamination through the "halo effect". Environmental Science \& Technology 49(3): 1303-1310.

69. Neves PA, Colabuono FI, Ferreira PA et al. (2018) Depositional history of polychlorinated biphenyls (PCBs), organochlorine pesticides (OCPs) and polycyclic aromatic hydrocarbons (PAHs) in an Amazon estuary during the last century. Science of the Total Environment 615: $1262-1270$.

70. Nizzetto L, Cassani C, Di Guardo A (2006) Deposition of PCBs in mountains: The forest filter effect of different forest ecosystem types. Ecotoxicology and Environmental Safety 63(1): 75-83.

71. Odabasi M, Ozgunerge Falay E, Tuna G, Altiok H, Kara M, Dumanoglu Y, Bayram A, Tolunay D, Elbir T (2015) Biomonitoring the spatial and historical variations of persistent organic 
pollutants (POPs) in an industrial region. Environmental Science \& Technology 49(4): 21052114.

72. Pavlova PA, Schmid P, Bogdal C, Steinlin C, Jenk TM, Schwikowski M (2014) Polychlorinated biphenyls in glaciers. 1. Deposition history from an Alpine ice core. Environmental Science \& Technology 48(14): 7842-7848.

73. Pavlova PA, Zennegg $M$, Anselmetti FS, Schmid P, Bogdal C, Steinlin C, Jäggi $M$, Schwikowski M (2016) Release of PCBs from Silvretta glacier (Switzerland) investigated in lake sediments and meltwater. Environmental Science and Pollution Research 23(11): $10308-10316$.

74. Pino NJ, Múnera LM, Peñuela GA (2019) Phytoremediation of soil contaminated with PCBs using different plants and their associated microbial communities. International Journal of Phytoremediation 21(4): 316-324.

75. Pittino F, Ambrosini R, Azzoni R, Diolaiuti G, Villa S, Gandolfi I, Franzetti A (2018) Postdepositional biodegradation processes of pollutants on glacier surfaces. Condensed Matter 3(3): 24.

76. Pouch A, Zaborska A, Pazdro K (2017) Concentrations and origin of polychlorinated biphenyls (PCBs) and polycyclic aromatic hydrocarbons (PAHs) in sediments of western Spitsbergen fjords (Kongsfjorden, Hornsund, and Adventfjorden). Environmental Monitoring and Assessment 189(4): 175. 
77. Risso F, Magherini A, Ottonelli M, Magi E, Lottici S, Maggiolo S, Garbarino M, Narizzano R (2016) A comprehensive approach to actual polychlorinated biphenyls environmental contamination. Environmental Science and Pollution Research 23(9): 8770-8780.

78. Rodenburg LA, Ralston DK (2017) Historical sources of polychlorinated biphenyls to the sediment of the New York/New Jersey Harbor. Chemosphere 169: 450-459.

79. Rose NL (2015) Spheroidal carbonaceous fly ash particles provide a globally synchronous stratigraphic marker for the Anthropocene. Environmental Science \& Technology 49(7): 4155-4162.

80. Ross PS, Jeffries SJ, Yunker MB, Addison RF, Ikonomou MG, Calambokidis JC (2004) Harbor seals (Phoca vitulina) in British Columbia, Canada, and Washington State, USA, reveal a combination of local and global polychlorinated biphenyl, dioxin, and furan signals. Environmental Toxicology and Chemistry: An International Journal 23(1): 157-165.

81. Sanders G, Jones KC, Hamilton-Taylor J, Dorr H (1995) PCB and PAH fluxes to a dated UK peat core. Environmental Pollution 89(1): 17-25.

82. Schmid P, Bogdal C, Blüthgen N, Anselmetti FS, Zwyssig A, Hungerbühler K (2011) The missing piece: sediment records in remote mountain lakes confirm glaciers being secondary sources of persistent organic pollutants. Environmental Science \& Technology 45(1): 203-208.

83. Schwarzbauer J, Jovančićević B (2018) Organic Pollutants. In: Schwarzbauer J, Jovančićević B (eds) Organic Pollutants in the Geosphere. Cham: Springer International Publishing, pp. 55-156. 
84. Sedlak DL, Andren AW (1991) Aqueous-phase oxidation of polychlorinated biphenyls by hydroxyl radicals. Environmental Science \& Technology 25(8): 1419-1427.

85. Sharma BM, Nizzetto L, Bharat GK, Tayal S, Melymuk L, Sáňka O, Přibylová P, Audy O, Larssen T (2015) Melting Himalayan glaciers contaminated by legacy atmospheric depositions are important sources of PCBs and high-molecular-weight PAHs for the Ganges floodplain during dry periods. Environmental Pollution 206: 588-596.

86. Shiu WY, Mackay D (1986) A critical review of aqueous solubilities, vapor pressures, Henry's law constants, and octanol-water partition coefficients of the polychlorinated biphenyls. Journal of Physical and Chemical Reference Data 15(2): 911-929.

87. Sobek A, Sundqvist KL, Assefa AT, Wiberg K (2015) Baltic Sea sediment records: Unlikely near-future declines in PCBs and HCB. Science of the Total Environment 518: 8-15.

88. Steinlin C, Bogdal C, Pavlova PA et al. (2015) polychlorinated biphenyls in a temperate alpine glacier: 2. Model results of chemical fate processes. Environmental Science \& Technology 49(24): 14092-14100.

89. Tang T, Zheng Z, Wang R, Huang K, Li H, Tao X, Dang Z, Yin H, Lu G (2018) Photodegradation behaviors of polychlorinated biphenyls in methanol by UV-irradiation: Solvent adducts and sigmatropic arrangement. Chemosphere 193: 861-868.

90. Tato L, Tremolada P, Ballabio C, Guazzoni N, Parolini M, Caccianiga M, Binelli A (2011) Seasonal and spatial variability of polychlorinated biphenyls (PCBs) in vegetation and cow milk from a high altitude pasture in the Italian Alps. Environmental Pollution 159(10): $2656-2664$. 
91. Terzaghi E, Zanardini E, Morosini C, Raspa G, Borin S, Mapelli F, Vergani L, DiGuardo A (2018) Rhizoremediation half-lives of PCBs: Role of congener composition, organic carbon forms, bioavailability, microbial activity, plant species and soil conditions, on the prediction of fate and persistence in soil. Science of the Total Environment 612: 544-560.

92. Thüns S, Blodau Ch, Radke M (2014) Evaluation of peat cores as archives of polychlorinated biphenyl deposition rates. In: Thüns S (ed) Application of the peat archive as tool in environmental chemistry. PhD thesis, University of Bayreuth.

93. Tombesi N, Pozo K, Álvarez M, Přibylová P, Kukučka P, Audy O, Klánová J (2017) Tracking polychlorinated biphenyls (PCBs) and polybrominated diphenyl ethers (PBDEs) in sediments and soils from the southwest of Buenos Aires Province, Argentina (South eastern part of the GRULAC region). Science of The Total Environment 575: 1470-1476.

94. Tourinho PS, Kočí V, Loureiro S, van Gestel CA (2019) Partitioning of chemical contaminants to microplastics: Sorption mechanisms, environmental distribution and effects on toxicity and bioaccumulation. Environmental Pollution 252: 1246-1256.

95. UNEP (2001) Stockholm Convention on POPs, Text and Annexes, Interim Secretariat for the Stockholm Convention on Persistent Organic Pollutants. Geneva, Switzerland: UNEP Chemicals.

96. Urbaniak M (2007) Polychlorinated biphenyls: Sources, distribution and transformation in the environment-a literature review. Acta Toxicologica 15(2): 83-93.

97. Vane CH, Chenery SR, Harrison I, Kim AW, Moss-Hayes V, Jones DG (2011) Chemical signatures of the Anthropocene in the Clyde estuary, UK: sediment-hosted Pb, ${ }^{207 / 206} \mathrm{~Pb}$, 
total petroleum hydrocarbon, polyaromatic hydrocarbon and polychlorinated biphenyl pollution records. Philosophical Transactions of the Royal Society of London A: Mathematical, Physical and Engineering Sciences 369(1938): 1085-1111.

98. Velzeboer I, Kwadijk CJAF, Koelmans AA (2014) Strong sorption of PCBs to nanoplastics, microplastics, carbon nanotubes, and fullerenes. Environmental Science \& Technology 48(9): 4869-4876.

99. Vorkamp K (2016) An overlooked environmental issue? A review of the inadvertent formation of PCB-11 and other PCB congeners and their occurrence in consumer products and in the environment. Science of the Total Environment 541: 1463-1476.

100. Wania F, Mackay D (1993) Global fractionation and cold condensation of low volatility organochlorine compounds in polar regions. Ambio 22: 10-18.

101. Waters CN, Syvitski JP, Gałuszka A et al. (2015) Can nuclear weapons fallout mark the beginning of the Anthropocene Epoch? Bulletin of the Atomic Scientists 71(3): 46-57.

102. Waters CN, Zalasiewicz J, Head MJ et al. (2019) Progress in the investigation for a potential Global Boundary Stratotype Section and Point (GSSP) for the Anthropocene Series. Strati2019 Abstract Book. Roma: Società Geologica Italiana, pp. 354.

103. Waters CN, Zalasiewicz J, Summerhayes C et al. (2018) Palaeoenvironmental archives and their differing suitabilities to provide candidate Global Boundary Stratotype Sections and Points (GSSPs) for the Anthropocene. Earth-Science Reviews 178: 379-429.

104. Waters CN, Zalasiewicz J, Summerhayes Cet al. (2016) The Anthropocene is functionally and stratigraphically distinct from the Holocene. Science 351(6269): aad2622. 
105. Williams M, Zalasiewicz J, Haff PK, Schwägerl C, Barnosky AD, Ellis EC (2015) The anthropocene biosphere. The Anthropocene Review 2(3): 196-219.

106. Wu Z, Lin T, Li A, Zhou S, He H, Guo J, Hu L, Li Y, Guo Z (2019) Sedimentary records of polychlorinated biphenyls in the East China Marginal Seas and Great Lakes: Significance of recent rise of emissions in China and environmental implications. Environmental Pollution 254: 112972.

107. Yang C, Rose NL, Turner SD et al. (2016) Hexabromocyclododecanes, polybrominated diphenyl ethers, and polychlorinated biphenyls in radiometrically dated sediment cores from English lakes, 1950-present. Science of the Total Environment 541: 721-728.

108. Yılmaz A, Karacık B, Yakan SD, Henkelmann B, Schramm KW, Okay OS (2016) Organic and heavy metal pollution in shipbreaking yards. Ocean Engineering 123: 452-457.

109. Yuan X, Yang X, Na G, Zhang A, Mao Y, Liu G, Wang L, Li X (2015) Polychlorinated biphenyls and organochlorine pesticides in surface sediments from the sand flats of Shuangtaizi Estuary, China: levels, distribution, and possible sources. Environmental Science and Pollution Research 22(18): 14337-14348.

110. Zalasiewicz J, Waters CN, do Sul JAI et al. (2016) The geological cycle of plastics and their use as a stratigraphic indicator of the Anthropocene. Anthropocene 13: 4-17.

111. Zalasiewicz J, Waters CN, Summerhayes C et al. (2017) The Working Group on the 'Anthropocene': Summary of evidence and recommendations. Anthropocene 19: 55-60. 
112. Zalasiewicz J, Waters CN, Williams M et al. (2015) When did the Anthropocene begin? A mid-twentieth century boundary level is stratigraphically optimal. Quaternary International 383: 196-203.

113. Zalasiewicz J, Williams M, Waters CN, Barnosky AD, Haff P (2014) The technofossil record of humans. The Anthropocene Review 1(1): 34-43.

114. Zennegg $M$, Kohler $M$, Hartmann PC et al. (2007). The historical record of PCB and PCDD/F deposition at Greifensee, a lake of the Swiss plateau, between 1848 and 1999. Chemosphere 67(9): 1754-1761.

115. Zhan Z, Wang J, Peng J, Xie Q, Huang Y, Gao Y (2016) Sorption of 3, 3', 4, 4'tetrachlorobiphenyl by microplastics: a case study of polypropylene. Marine Pollution Bulletin 110(1): 559-563.

116. Zhao S, Breivik K, Liu G, Zheng M, Jones KC, Sweetman AJ (2017) Long-term temporal trends of polychlorinated biphenyls and their controlling sources in China. Environmental Science \& Technology 51(5): 2838-2845. 


\section{Figure captions}

Fig. 1. A molecule of polychlorinated biphenyl. Different numbers of chlorine atoms $(m+n)$ can be incorporated in $2,2^{\prime}, 6,6^{\prime}$ (ortho-), 3,3',5,5' (meta-) and 4,4' (para-) positions.

Fig. 2. Percentage of individual PCB homologues produced globally. Data compiled from Breivik et al., 2007.

Fig. 3. Examples of trends in PCB concentrations in dated environmental archives: $A-$ Fiescherhorn glacier, Switzerland (Pavlova et al., 2014); B - Seine River basin, France (Lorgeoux et al., 2016); Great Lakes, North America and East China Marginal Seas (Wu et al., 2019). 


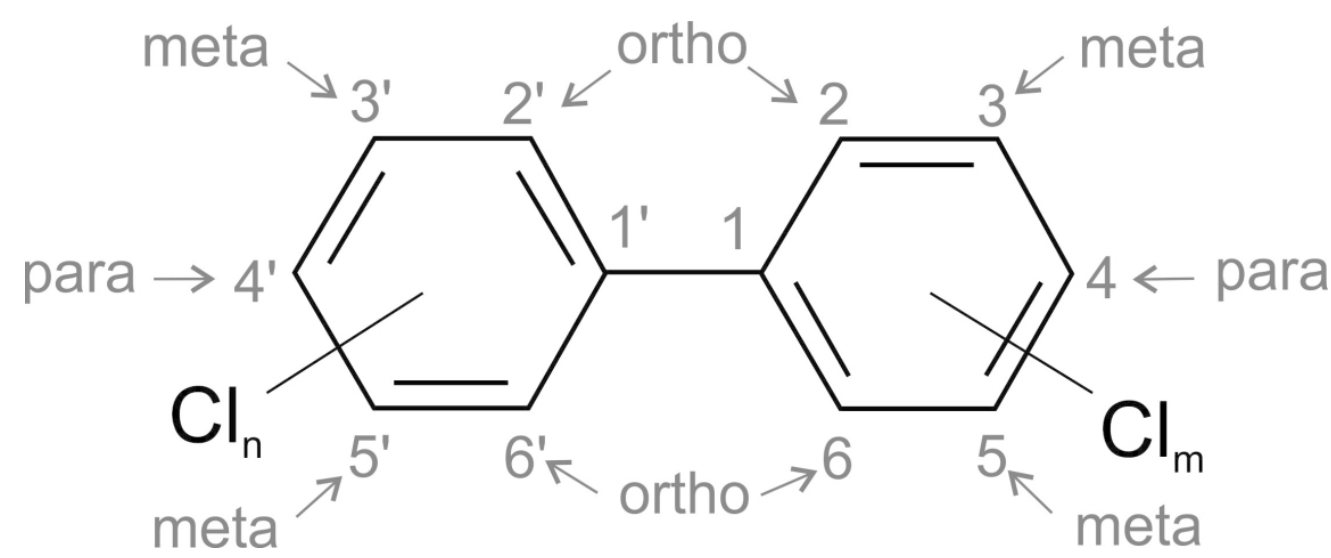

A molecule of polychlorinated biphenyl. Different numbers of chlorine atoms $(m+n)$ can be incorporated in $2,2^{\prime}, 6,6^{\prime}$ (ortho-), 3,3',5,5' (meta-) and 4,4' (para-) positions.

$95 \times 38 \mathrm{~mm}(600 \times 600 \mathrm{DPI})$ 


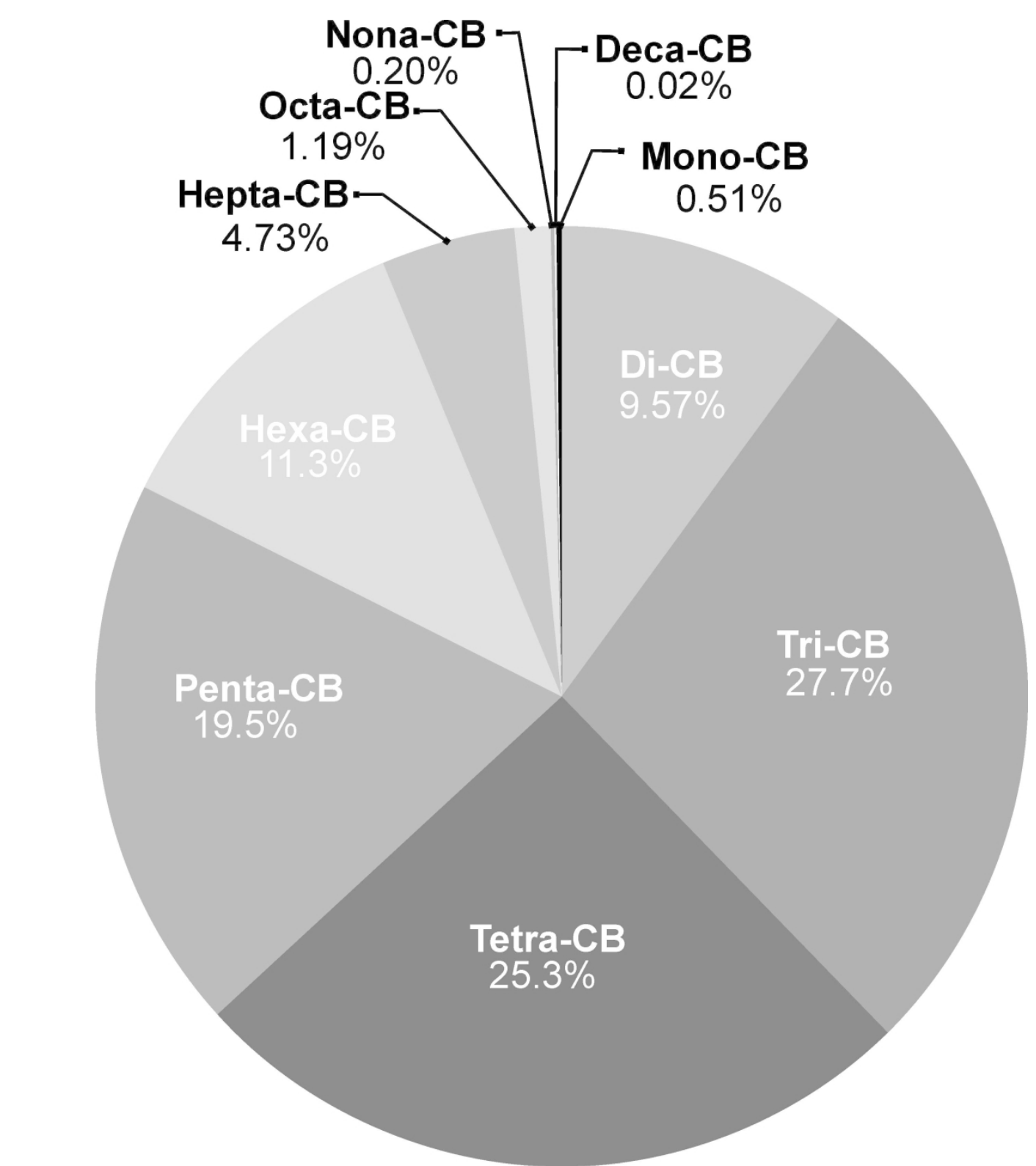

Percentage of individual PCB homologues produced globally. Data compiled from Breivik et al., 2007. $121 \times 148 \mathrm{~mm}(600 \times 600 \mathrm{DPI})$ 


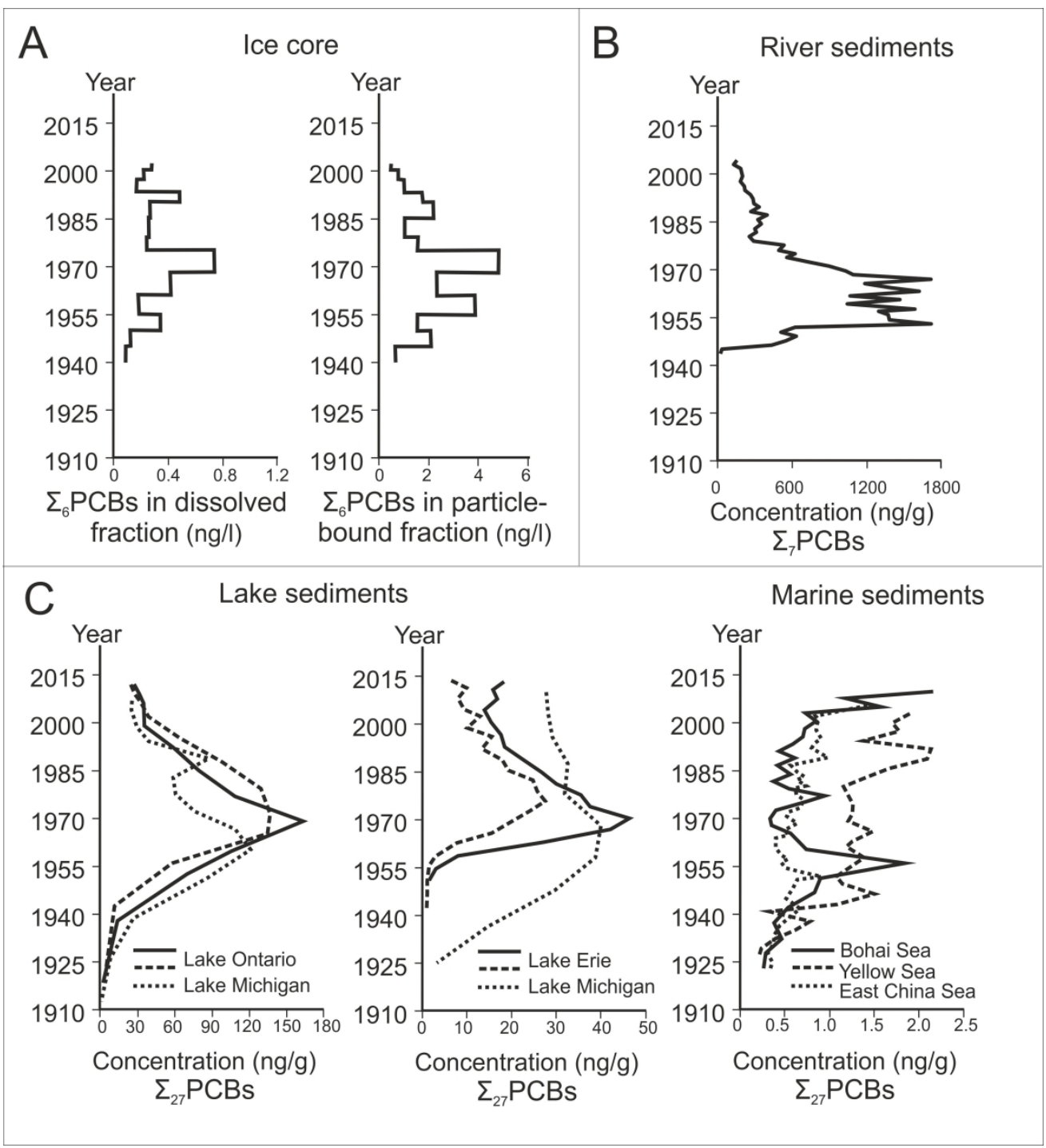

Examples of trends in PCB concentrations in dated environmental archives: A - Fiescherhorn glacier, Switzerland (Pavlova et al., 2014); B - Seine River basin, France (Lorgeoux et al., 2016); Great Lakes, North America and East China Marginal Seas (Wu et al., 2019).

$149 \times 163 \mathrm{~mm}(600 \times 600 \mathrm{DPI})$ 
Table 1. Data on production of PCBs (compiled from de Voogt and Brinkman, 1989; IARC, 2016 and references cited therein).

\begin{tabular}{lllll}
\hline Country & Start (year) & End (year) & Peak production (year) & Amount (tonnes) \\
\hline USA & 1930 & 1977 & 1970 & 641,700 \\
Germany & 1930 & 1983 & 1974 & 159,062 \\
Russia & 1939 & 1993 & $1980 \mathrm{~s}$ & 173,800 \\
France & 1930 & 1984 & 1978 & 134,654 \\
United Kingdom & 1954 & 1977 & Late 1960s & 66,542 \\
Japan & 1954 & 1972 & 1970 & 58,787 \\
Italy & 1958 & 1983 & 1973 & 31,092 \\
Democratic Republic of Korea & 1960 & 2012 & Late 1980s & 30,000 \\
Spain & 1955 & 1984 & 1975 & 29,012 \\
Czechoslovakia & 1959 & 1984 & Unspecified & 21,482 \\
China & 1965 & 1980 & Mid-1970s & 10,000 \\
Poland & 1966 & 1977 & Unspecified & 1679 \\
\hline
\end{tabular}


Table 2. Examples of peak PCB concentrations found in different environmental archives in remote areas

\begin{tabular}{|c|c|c|c|c|c|c|}
\hline $\begin{array}{l}\text { Environmental } \\
\text { archive }\end{array}$ & Location & Dating method & Peak concentration & $\begin{array}{l}\text { Year(s) of peak } \\
\text { concentrations }\end{array}$ & $\begin{array}{l}\text { Number of } \\
\text { congeners }\end{array}$ & Reference \\
\hline \multirow[t]{2}{*}{ Glacial ice } & Lomonosovfonna glacier, Svalbard, Arctic & $\delta^{18} \mathrm{O}$ annual layer counting & $1.5 \mathrm{ng} / \mathrm{L}$ & $1957-1966$ & 209 & Garmash et al., 2013 \\
\hline & Fiescherhorn glacier, Switzerland & $\begin{array}{l}\text { annual layer counting, } \\
\text { Saharan dust, }{ }^{3} \mathrm{H},{ }^{137} \mathrm{Cs}\end{array}$ & $5 \mathrm{ng} / \mathrm{L}$ & 1970 s & 6 & Pavlova et al., 2014 \\
\hline \multirow[t]{2}{*}{ Snow/firn } & Talos Dome (Antarctica) & ${ }^{3} \mathrm{H}$, volcanic sulfate & $0.24 \mathrm{ng} / \mathrm{L}$ & 1980s-1990s & 7 & Fuoco et al., 2012 \\
\hline & Western Anctarctic Penninsula & not applicable & $1.1 \mathrm{ng} / \mathrm{L}$ & not applicable & 29 & Khairy et al., 2016 \\
\hline \multirow{3}{*}{$\begin{array}{l}\text { Lacustrine } \\
\text { sediments }\end{array}$} & Silvretta Lake (proglacial lake), Swiss Alps & ${ }^{137} \mathrm{Cs},{ }^{239} \mathrm{Pu},{ }^{241} \mathrm{Am}$ & $0.80 \mathrm{ng} / \mathrm{g}$ & $1960 \mathrm{~s}$ & 6 & Pavlova et al., 2016 \\
\hline & $\begin{array}{l}\text { High mountain lakes: Lake Redon, Spain } \\
\text { (a); Długi Staw, Poland (b); Ladove, } \\
\text { Slovakia (c) }\end{array}$ & ${ }^{210} \mathrm{~Pb},{ }^{137} \mathrm{Cs},{ }^{241} \mathrm{Am}$ & $\begin{array}{l}2.3 \mathrm{ng} / \mathrm{g} \\
15 \mathrm{ng} / \mathrm{g} \\
10 \mathrm{ng} / \mathrm{g}\end{array}$ & $\begin{array}{l}1994 \\
1990 s \\
1976-1997\end{array}$ & 11 & Grimalt et al., 2004 \\
\hline & $\begin{array}{l}\text { Mt. Everest (samples from } 8 \text { lakes in } \\
\text { Khumbu and Imja Valley) }\end{array}$ & not applicable & $84.3 \mathrm{ng} / \mathrm{g}^{*}$ & not applicable & 14 & Guzzella et al., 2016 \\
\hline \multirow[t]{7}{*}{$\begin{array}{l}\text { Marine } \\
\text { sediments }\end{array}$} & $\begin{array}{l}\text { Admiralty Bay, King George Island, } \\
\text { Antarctica }\end{array}$ & ${ }^{137} \mathrm{Cs}$ & $11.9 \mathrm{ng} / \mathrm{g}$ & 1983-1986 & 7 & Combi et al., 2017 \\
\hline & Western Spitsbergen fjords, Arctic & ${ }^{210} \mathrm{~Pb}$ & $1.47 \mathrm{ng} / \mathrm{g}$ & 2011-2013 & 7 & Pouch et al., 2017 \\
\hline & Bering Sea & not applicable & $0.088 \mathrm{ng} / \mathrm{g}$ & not applicable & 46 & Ma et al., 2015 \\
\hline & Bering Strait & not applicable & $0.708 \mathrm{ng} / \mathrm{g}$ & not applicable & 46 & Ma et al., 2015 \\
\hline & Chukchi Sea & not applicable & $1.0 \mathrm{ng} / \mathrm{g}$ & not applicable & 46 & Ma et al., 2015 \\
\hline & Iceland Station, Arctic & not applicable & $203 \mathrm{ng} / \mathrm{g}$ & not applicable & 46 & Ma et al., 2015 \\
\hline & Mariana Trench & not applicable & $4.2 \mathrm{ng} / \mathrm{g}$ & not applicable & 36 & Dasgupta et al., 2018 \\
\hline
\end{tabular}


Table 3. Examples of PCB concentrations found in different environmental archives in polluted areas

\begin{tabular}{|c|c|c|c|c|c|c|}
\hline $\begin{array}{l}\text { Environmental } \\
\text { archive }\end{array}$ & Location & Dating method & $\begin{array}{l}\text { Peak concentration } \\
(\mathrm{ng} / \mathrm{g})\end{array}$ & $\begin{array}{l}\text { Year(s) of peak } \\
\text { concentrations }\end{array}$ & $\begin{array}{l}\text { Number of } \\
\text { congeners }\end{array}$ & Reference \\
\hline \multirow{6}{*}{$\begin{array}{l}\text { Estuarine } \\
\text { sediments }\end{array}$} & Buenos Aires Province, Argentina & not applicable & 17.6 & not applicable & 7 & Tombesi et al., 2017 \\
\hline & Guajará Bay, Brazil & ${ }^{210} \mathrm{~Pb}$ and ${ }^{137} \mathrm{Cs}$ & 4.58 & early 1990s & 51 & Neves et al., 2018 \\
\hline & $\begin{array}{l}\text { New York/New Jersey Harbor and Lower } \\
\text { Hudson River }\end{array}$ & ${ }^{137} \mathrm{Cs}$ & $36,100 *$ & 1970s & 132 & $\begin{array}{l}\text { Rodenburg and Ralston, } \\
2017\end{array}$ \\
\hline & Clyde estuary, UK & $207 / 206 \mathrm{~Pb}$ & 5797 & 1965-1977 & 7 & Vane et al., 2011 \\
\hline & Liaohe Estuary & not applicable & 16.6 & not applicable & not specified & Li et al., 2017 \\
\hline & Shuangtaizi Estuary & not applicable & 36.68 & not applicable & 28 & Yuan et al., 2015 \\
\hline & Coastal area of the Aegean Sea & not applicable & 847 & not applicable & 18 & Yılmaz et al., 2016 \\
\hline \multirow[t]{4}{*}{ sediments } & Coastal area of Ionian Sea, S Italy & not applicable & 1684 & not applicable & not specified & Cardellicchio et al., 2007 \\
\hline & Bohai Sea, China & ${ }^{210} \mathrm{~Pb}$ & 2.16 & 1975 & 27 & Wu et al., 2019 \\
\hline & South Yellow Sea, China & ${ }^{210} \mathrm{~Pb}$ & 2.20 & 2000 & 27 & Wu et al., 2019 \\
\hline & East China Sea & ${ }^{210} \mathrm{~Pb}$ & 1.21 & 2010 & 27 & Wu et al., 2019 \\
\hline Fluvial & Seine River basin, France & ${ }^{137} \mathrm{Cs}$ & 2300 & 1960 & 15 & Lorgeoux et al., 2016 \\
\hline \multirow[t]{2}{*}{ sediments } & Mondego River, Central Portugal & not applicable & 5.3 & not applicable & 10 & Dias-Ferreira et al., 2016 \\
\hline & Nara River, Central Russia & not applicable & $119,000 * *$ & not applicable & 7 & Malina and Mazlova, 2017 \\
\hline Lacustrine & Lake Bourget, France & not applicable & 18 & not applicable & 7 & Lécrivain et al., 2018 \\
\hline \multirow[t]{6}{*}{ sediments } & Lake Greifensee, Switzerland & ${ }^{137} \mathrm{Cs}$ & 132 & $1957-1960$ & 6 & Zennegg et al., 2007 \\
\hline & Lake Manzala, Egypt & not applicable & 31.27 & not applicable & 7 & Barakat et al., 2012 \\
\hline & Lake Chaohu, China & not applicable & 4 & not applicable & 34 & He et al., 2016 \\
\hline & Lake Michigan & ${ }^{210} \mathrm{~Pb}$ & 121 & 1960s-1970s & 27 & Wu et al., 2019 \\
\hline & Lake Ontario & ${ }^{210} \mathrm{~Pb}$ & 165 & 1960s-1970s & 27 & Wu et al., 2019 \\
\hline & Lake Erie & ${ }^{210} \mathrm{~Pb}$ & 46.4 & $1960 s-1970 s$ & 27 & Wu et al., 2019 \\
\hline \multirow[t]{2}{*}{ Peat core } & Cheshire, NW England & $\begin{array}{l}{ }^{210} \mathrm{~Pb},{ }^{137} \mathrm{Cs},{ }^{241} \mathrm{Am} \text {, pollen, } \\
\text { magnetics }\end{array}$ & 36.8 & 1964 & 25 & Sanders et al., 1995 \\
\hline & SW Switzerland & ${ }^{210} \mathrm{~Pb}$ & 19 & 1960-1976 & 7 & Berset et al., 2001 \\
\hline \multirow[t]{2}{*}{ Coral reefs } & Egyptian Red Sea Coast & not applicable & 48.3 & not applicable & 7 & El Nemr et al., 2004 \\
\hline & French Frigate Shoals, Pacific Ocean & not applicable & 267 & not applicable & 17 & Miao et al., 2000 \\
\hline
\end{tabular}

